\title{
Araștırma Makalesi \\ Tuz Oranı Değişiminin Kırmızı Pul Biberin Toz Akış Özellikleri Üzerine Etkisi
}

\author{
Duygu ASLAN TÜRKER ${ }^{1}$, Meryem GÖKSEL SARAÇ ${ }^{2}$, Mahmut DOĞAN ${ }^{1 *}$
}

\begin{abstract}
ÖZ
Bu çalışmada kırmızı pul bibere farklı oranlarda tuz ilave edilmesinin ürünün fizikokimyasal ve toz akış özellikleri üzerinde oluş̧urduğu etkiler belirlenmiştir. Bu amaçla \%3, 5 ve 7 oranında tuz, pul bibere ilave edilmiş ve homojen karışımlar elde edildikten sonra analizler yapılmıştır. Örneklerin nem, su aktivitesi ve renk analizleri, yığın ve sıkıştıılmış yoğunluk, Carr indeksi, Hausner oranları ile kohezyon, kekleşme ve toz akış hızı bağımlılık (PFSD) testleri yapılmıştır. Çalışma sonucunda pul biberlere farklı oranlarda tuz ilavesinin ürünlerin yığın ve sıkıştırılmış yoğunluk, kohezyon ve akış özelliklerini geliştirdiği bu sayede ürün işleme süreçlerini olumlu etkilediği belirlenmiştir. Elde edilen sonuçlar, en iyi yığın yoğunluğu ve sıkıştırılmış yığın yoğunluğu değerlerinin tuz oranının fazla olduğu PB5 ve PB7 örneklerine ait olduğunu göstermiştir.
\end{abstract}

Anahtar Kelimeler: pul biber, tuz, toz özellik, toz akış, kekleşme

\section{Effect of Salt Content Variations on Powder Flow Properties of Red Peppers}

\section{ABSTRACT}

In this study, the effects of adding different amounts of salt to red peppers on the physicochemical and powder flow properties of the product were determined. For this purpose, 3, 5 and $7 \%$ salt was added to the red pepper and analyzes were made after obtaining homogeneous mixtures. Moisture, water activity and color bulk and tapped bulk density, Carr index, Hausner ratios as well as the cohesion, caking and powder flow speed dependency (PFSD) tests of the samples were performed. As a result of the study, it was determined that adding different amounts of salt to red powder peppers improved the bulk and tapped bulk density, cohesion and flow properties of the products, thus positively affecting the product processing processes. The results showed that the best bulk density and tapped bulk density values belong to PB5 and PB7 samples which has higher salt content.

Keywords: red powder pepper, salt, powder properties, powder flow, caking

ORCID ID (Yazar sirasina göre)

0000-0002-9579-8347, 0000-0002-8190-2406, 0000-0003-1639-4641

Yayın Kuruluna Geliş Tarihi: 27.04.2021

Kabul Tarihi: 24.10.2021

${ }^{1}$ Erciyes Üniversitesi, Mühendislik Fakültesi, Gıda Mühendisliği, Kayseri

${ }^{2}$ Sivas Cumhuriyet Üniversitesi, Yıldızeli Meslek Yüksekokulu, Gıda Teknolojisi, Sivas

*E-posta: dogan@erciyes.edu.tr 


\section{Tuz Oranı Değişiminin Kırmızı Pul Biberin Toz Akış Özellikleri Üzerine Etkisi}

\section{Giriș}

Kırmızıbiber (Capsicum annuиm L.) kendine özgün tadı ile dünya genelinde yaygın tarımı yapılan, taze ve kurutulmuş olarak tüketilen bir gıda ürünüdür (Rico ve ark., 2010). Kırmızı biberin kurutulup farklı boyutlarda öğütülmesi sonucunda toz biber ve pul biber olarak tanımlanan baharatlar elde edilmektedir. Baharat olarak kullanılan kırmızıbiber dünya genelinde baharatlar içerisinde en çok tüketilen üründür ve talebi her geçen gün artmaktadır (Gobie, 2019). Elde edilen toz biberlerin rengi tüm dünyada ticari olarak belirleyici kriter olmaktadır (Arimboor ve ark., 2015). Toz kırmızı biberler genel olarak gidaların renk, tat ve lezzet bileșenlerini artırmak için kullanılmaktadır (Staack ve ark., 2008). Tüm dünyada ve ülkemizde kullanımı bu kadar yaygın olan toz biberlerin kurutma, depolama, işleme ve dağıtma süreçlerinde mikrobiyal kontaminasyona açık olduğu ve hijyen kuralları açısından riskler taşıdığ1 bilinmektedir (Schweiggert ve ark., 2007).

Pul biber ve isotlara üretimleri sirasında tuz katılmaktadır ve bu durum biberlerin düşük su aktivitesine sahip olmalarını sağlamaktadır (Korkmaz ve ark., 2020). Pul biberlerin yaklaşık $\% 4$ oranında tuz ve $\% 12$ oranında yağ içerdiği bilinmektedir (Zhang ve ark., 2020). Kurutulmuş ürünlerde suyun uzaklaşması ile ürün yapısında bulunan tuz ve asit gibi bileşenler mikrobiyal bozulmaların önüne geçmektedir ayrıca pul biber üretiminde tuz mikrobiyal bozulmay1 önlemek için eklenmektedir (Dağhan, 2015). Tuz ayrıca kullanıldığ 1 ürünlere tat vermekte, mevcut tadın hissiyatını artırmakta ve tekstürde iyileştirmeler yapmaktadır (Akgün ve ark., 2018).

Toz gıdalar tek bir ürün grubunu ifade ettiği gibi birden fazla ve farklı toz ürünün birleşimi ile oluşan ürün gruplarını da içermektedir. Tozların fiziksel özellikleri işleme, nakliye ve depolama sürecindeki davranışlarını açıklamaktadır (Jaya ve Das, 2004). Fiziksel özelliklerden biri olan toz akış, tozların yığın halde komşu partiküller ve bulundukları ortamın (gıda işleme proses ekipmanları ve ambalaj vb.) yüzeylerindeki hareketin tanımıdır (Mitra ve ark., 2017). Toz akışını etkileyen parametreler partikül boyutu gibi fiziksel özellikler olabildiği gibi, ürünün yağ, protein, karbonhidrat ve nem içerikleri gibi kimyasal özellikler de olmaktadır (AlonsoMiravalles ve ark., 2020).

Gıda tozları elde edilme şekilleri ve ürünün doğası gereği değişiklik göstermekle birlikte farklı formlarda elde edilmektedir. Ögütülmüş gıda örneklerinde ögütme şekli süresi vb. faktörlerden etkilenmekle beraber düzensiz şekilde ürünler elde edilirken nişasta gibi ürünler küresel-oval, tuz ve şeker gibi ürünler ise kristal yapılardadır (Dhanalakshmi ve ark., 2011). Toz akış özelliklerini etkileyen önemli parametrelerden olan partikül boyutu değerlendirildiğinde büyük partikül boyutuna sahip tozların diğer partiküllerle temas alanının düşük olması nedeniyle daha akışkan oldukları görülmektedir (Teunou ve ark., 1999). Toz akış1 etkileyen fiziksel ve kimyasal parametreler göz önüne alınarak gıda ürünlerine kekleşme önleyici katkı maddeleri ilave edilmektedir. Genel olarak kekleşme önleyici katkılar sebze, içecek ve meyve tozları, yumurta tozu, toz çorbalar, maya tozu, şekerleme ürünleri, süt, kahve, krema tozları ve baharatlar gibi gida ürünlerinde geniş kullanım alanı bulmaktadır. Bazı gıda ürünlerinde ise toz ya da granül yapıda kekleşme önleyici ajanlar kullanılmaktadır (Lück ve von Rymon Lipinski, 2000). Aliminyum, kalsiyum ve demir amonyum sitrat tuzlarının kekleşme önleyici olarak kullanıldığ bilinen gida katk1 maddelerindendir (Yapıc1 ve ark., 2021).

Toz kırmızıbiberlere bulaşı kaynağı olan mikroorganizmalar ve inaktivasyon yöntemleri ile alakalı son dönemlerde oldukça fazla çalışma yapılmıştır (Choi ve ark., 2018; Jiao ve ark., 2019; Lee ve ark., 2020; Zhang ve ark., 2020). Öte yandan maillard reaksiyonları (Song ve ark., 2021), depolama sürecindeki karotenoid ve kapsaisinoid bileşim değişimi (Giuffrida ve ark., 2014), aroma ve fenolik karakteristiği (Guclu ve ark., 2021) gibi kimyasal ürün karakteristiklerinde meydana gelen değişimlerde incelenmiştir. Fakat ürün işleme proseslerine dahil olan ve ambalajlanıp tek başına ya da toz ürün grupları içerisinde satışa sunulan pul biberlerin toz akış özellikleri hakkında herhangi bir çalışma yapılmamıştır. 


\section{Tuz Oranı Değişiminin Kırmızı Pul Biberin Toz Akış Özellikleri Üzerine Etkisi}

Gıda tozlarının kimyasal ve fiziksel özellikleri toz akış davranışlarını etkilemektedir. Bu çalıșmada ticari olarak satıșında tuz kullanımına izin verilen ve kimyasal yapısı gereği kekleşmeye müsait olan pul biberler kullanılmıştır. Çalışma kapsamında taze alınmış pul biberlere farkl1 oranlarda $(\% 3,5$ ve 7$)$ tuz eklenmiş ve tuz oranı değişimi ile ürün özelliklerinde meydana gelen değişimler fizikokimyasal ve toz akış özellikleri açısından incelenmiştir.

\section{Materyal ve Yöntem Materyal}

Çalışmada kullanılan kırmızı pul biberler 2020 y1lı Ekim ayında Kayseri (Cirgalan, Kocasinan, Kayseri)'de bulunan yerel üreticilerden herhangi bir katk1 maddesi ilave edilmeden doğrudan temin edilmiştir. $\mathrm{NaCl}$ oranının pul biberlerin toz akış özelliklerinde meydana getirdiği değişimin incelenmesi için de kontrol örneğine ek olarak pul biberlere $\% 3, \% 5$ ve $\% 7(\mathrm{w} / \mathrm{w})$ oranında $\mathrm{NaCl}$ eklenmiştir. Analizlerde kullanılan örnekler PB3, PB5 ve PB7 olarak içerdikleri tuz oranına göre kodlanmış ve tuz içermeyen pul biber ise Kontrol-PB olarak ifade edilmiştir.

Yöntem

\section{Fizikokimyasal Özellikler}

Hazırlanan numunelerin nem içeriği Kirk ve Sawyer, (1991)'in kullandiğı metoda göre belirlenmiştir. Örneklerin CIE lab renk değerleri olarak bilinen $L^{*}, a^{*}$ ve $b^{*}$ verileri renk tayin cihazı (Konica-Minolta, CR400, Japonya) kullanılarak, su aktivitesi değeri ise su aktivitesi tayin cihazı (Aqua Lab 2.0, ABD) ile oda sıcaklığında tespit edilmiştir.

\footnotetext{
Yığın Yoğunluk ve Sıkıştırılmış Yığın Yoğunluk

Numunelerin yığın yoğunluğunun belirlenmesi için belirli miktardaki örnek hacmi sabit ve bilinen bir cam malzeme (50 mL'lik mezür) içerisine hiç bir sarsıntı ve titreşim olmaksızın konularak tartılması ile hesaplanmıştır ( $\rho_{\text {yı̆̆n }}$ $\mathrm{g} / \mathrm{cm}^{3}$ ). Örneklerin sıkıştırılmış yığın yoğunluğu değerleri ise aynı cam malzemede bulunan numunenin sert bir zemine saniyede bir vuruş olacak şekilde $180 \mathrm{kez}$ vurulması ve hacminin ölçülerek oranlanması suretiyle belirlenmiştir $\left(\rho_{\text {sikıştriılmıs }} \mathrm{g} / \mathrm{cm}^{3}\right)($ Tatar, 2012).
}

\section{Carr İndeks ve Hausner Oranı}

Toz ürünlerin kohezyon özelliklerine göre sınıflandırılmasında ve akış özelliklerinin değerlendirilmesinde kullanılan Carr indeksi ve Hausner oranı değerleri aşağıda verilen bağıntılarla hesaplanmıştır (Jan ve ark., 2015):

$$
\begin{aligned}
& \text { Carr indeksi }=\frac{\rho \text { sıkıștırılmış- }- \text { yıı̆ın }}{\rho \text { sıkışıııılmış }} \times 100 \\
& \text { Hausner } \text { oran } \iota=\frac{\rho \text { sıkıștırılmış }}{\rho y ı \text { ğın }}
\end{aligned}
$$

\section{Toz Akış Özellikleri}

Çalışma kapsamında hazırlanan pul biberlerin toz akış özellikleri tekstür cihazına (Stable Micro System, TAXT2 Plus, İngiltere) entegre yatay ve dikey düzlemde hareket eden toz akış probu kullanılarak ölçülmüştür. Toz akış özelliklerinin belirlenmesinde $50 \mathrm{~mm}$ iç çapı ve $120 \mathrm{~mm}$ yüksekliği olan cam silindir kullanılmıştır. Numunelerin kohezyon, kekleşme ve toz akış hızı bağımlılık (PFSD) testleri sonucunda elde edilen veriler cihaza ait yazılım (Texture Exponent 32) ile hesaplanmıştır.

\section{İstatistiksel Analiz}

Çalışma sonucunda elde edilen verilerin istatistiksel analizi Minitab (Windows Sürüm 18 için MINITAB) paket programı kullanılmıştır. Analiz sonucunda elde edilen verilerin değerlendirilmesinde tek yönlü varyans analizinden yararlanılmış ve Tukey testi ile de numuneler arası farklar yorumlanmıştır.

\section{Bulgular ve Tartışma \\ Fizikokimyasal Özellikler}

Pul biber örneklerine tuz ilavesinin ürünlerin fizikokimyasal özelliklerinde oluşturduğu etkilerin belirlenmesi için yapılan nem miktarı, su aktivitesi ve renk analiz sonuçları Çizelge 1'de verilmiştir. Tuz ilavesinin ve oran değişiminin pul biberde nem ve su aktivitesi değerlerinde istatistiksel açıdan önemli kabul edilecek bir değişime neden olmadığ 1 tespit edilmiştir ( $p>0.05)$. Örneklerin nem miktarları \%16.30-16.68 aralığında, su aktivitesi değerleri ise 0.23 olarak belirlenmiştir. Gida tozlarında düşük su aktivitesi ve nem içeriği ürünlerin 


\section{Tuz Oranı Değişiminin Kırmızı Pul Biberin Toz Akış Özellikleri Üzerine Etkisi}

mikrobiyolojik ve fiziksel özelliklerinin korunabilmesi için önem arz etmektedir. Su aktivitesinin düşük olması mikrobiyolojik açıdan gıda muhafazası için temel kriterlerdendir. Özellikle baharatların birçok gıda kökenli patojen (Salmonella, Cronobacter, Clostridium ve Bacillus) için kaynak olduğu bilinmektedir (Chitrakar ve ark., 2018). Diğer taraftan nem içeriğinin toz akış özelliklerini etkilediği ve yüksek nem içeriğinin de toz akışkanlığını azalttığı ifade edilmektedir (Zou ve Brusewitz, 2002).

Örneklerin renk değerleri incelendiğinde $L^{*}, a^{*}$ ve $b^{*}$ değerlerinin tuz oranı arttıkça artış gösterdiği belirlenmiştir. $L^{*}$ değeri açıklıkkoyuluk göstergesidir ve pul biber örneklerinde kontrol ürünü için 35.94, PB7 örneği için 41.63 olarak tespit edilmiştir $(\mathrm{p}<0.05)$. Tuzun beyaz renkli bir ürün olması nedeniyle, pul biberdeki oranı arttıkça pul biberlerin parlaklığı artmıştır.

Çizelge 1. Pul biber örneklerinin fizikokimyasal özellikleri

\begin{tabular}{llllll}
\hline \multirow{2}{*}{ Örnekler } & \multirow{2}{*}{$\begin{array}{l}\text { Nem Miktar1 } \\
(\%)\end{array}$} & $\mathrm{a}_{\mathrm{w}}$ & \multicolumn{4}{l}{ Renk Özellikleri } \\
\cline { 3 - 6 } & & & $L^{*}$ & $a^{*}$ & $b^{*}$ \\
\hline Kontrol-PB & $16.68 \pm 0.24$ & $0.23 \pm 0.00$ & $35.94 \pm 0.01^{\mathrm{d}}$ & $19.36 \pm 0.03^{\mathrm{d}}$ & $14.02 \pm 0.02^{\mathrm{d}}$ \\
PB3 & $16.30 \pm 0.11$ & $0.23 \pm 0.00$ & $36.57 \pm 0.01^{\mathrm{c}}$ & $19.63 \pm 0.02^{\mathrm{c}}$ & $15.28 \pm 0.02^{\mathrm{c}}$ \\
PB5 & $16.33 \pm 0.25$ & $0.23 \pm 0.01$ & $39.50 \pm 0.01^{\mathrm{b}}$ & $20.19 \pm 0.02^{\mathrm{b}}$ & $17.15 \pm 0.01^{\mathrm{b}}$ \\
PB7 & $16.42 \pm 0.09$ & $0.23 \pm 0.00$ & $41.63 \pm 0.01^{\mathrm{a}}$ & $22.31 \pm 0.02^{\mathrm{a}}$ & $21.73 \pm 0.04^{\mathrm{a}}$
\end{tabular}

*Aynı sütundaki farklı küçük harfle belirtilen değerlerin istatistiksel olarak önemli ölçüde farklı olduğunu belirtmektedir. $\mathrm{p}<0.05$. ortalama \pm ;standart sapma

$a^{*}$ değeri sonuçları $+a^{*}$ yönde olduğunda örnek kırmızı, $-a^{*}$ yönde olduğunda yeşil karakteristik göstermektedir. Pul biber örneklerinin $a^{*}$ değerleri 19.36-22.31 aralığında belirlenmiştir $(\mathrm{p}<0.05)$. Pul biberlerde tuz konsantrasyonu artışı ile artan $a^{*}$ değeri, tuz ilavesinin pul biberlerde oluşturduğu kekleşmeyle daha sıkı bir yapı oluşması ve pul biberlerin daha kırmızı görünmesi şeklinde açıklanabilir.

$+b^{*}$ yönde sarı $v e-b^{*}$ yönde ise mavi rengi ifade eden $b^{*}$ değeri pul biber örnekleri için 14.02 değeri ile Kontrol-PB ürününde en düşük, 21.73 değeri ile PB7 ürününde en yüksek olarak belirlenmiştir $(\mathrm{p}<0.05)$. Yapılan literatür taramaları sonucunda pul biberde renk değerlerinin genel olarak üretim aşamasında kurutma süresi ve sicakl1k değeri gibi değişkenlerden nasıl etkilendiği yönünde olduğu görülmüştür. Benzer şekilde farklı kurutma tekniklerinin pul biber üretiminde denendiği bir çalışmada $L^{*}, a^{*}$ ve $b^{*}$ değerlerinin sirasıyla $23.37-26.81, \quad 21.31-24.67$ ve 7.32-11.46 aralığında olduğu tespit edilmiştir (Dağhan, 2015). Organik ve geleneksel üretim yöntemi ile elde edilen taze kırmızıbiberlerden alternatif toz biber üretim tekniklerinin araştırıldığ 1 bir çalışmada $L *$ değerleri 53.51-61.11, $a^{*}$ değerleri 24.86-32.69 ve $b^{*}$ değerleri 35.22-41.16 aralığında tespit edilmiş ve renk özelliklerinin uygulanan kurutma tekniğinden etkilendiğinden bahsetmişlerdir (Guclu ve ark., 2021).

\section{Toz Özellikler}

Pul biber örneklerinin toz özellikleri olarak ifade edilen yığın ve sıkıştırılmış yoğunluk, Carr indeks ve Hausner oran değerleri Çizelge 2'de verilmiştir. 
Çizelge 2. Ürünlerin toz özellikleri

\begin{tabular}{lllll}
\hline Örnekler & $\begin{array}{l}\text { Yiğın Yoğunluk } \\
\left(\mathrm{g} / \mathrm{cm}^{3}\right)\end{array}$ & $\begin{array}{l}\text { Sikıştırılmış } \\
\text { Yoğunluk } \\
\left(\mathrm{g} / \mathrm{cm}^{3}\right)\end{array}$ & Carr indeks (\%) & Hausner Oranı \\
\hline Kontrol-PB & $0.39 \pm 0.00^{\mathrm{c}}$ & $0.48 \pm 0.01^{\mathrm{c}}$ & $18.67 \pm 1.15^{\mathrm{b}}$ & $1.23 \pm 0.02^{\mathrm{b}}$ \\
PB3 & $0.38 \pm 0.00^{\mathrm{c}}$ & $0.48 \pm 0.01^{\mathrm{c}}$ & $20.67 \pm 1.15^{\mathrm{ab}}$ & $1.26 \pm 0.02^{\mathrm{ab}}$ \\
PB5 & $0.41 \pm 0.00^{\mathrm{b}}$ & $0.52 \pm 0.00^{\mathrm{b}}$ & $22.00 \pm 0.00^{\mathrm{a}}$ & $1.28 \pm 0.00^{\mathrm{a}}$ \\
PB7 & $0.43 \pm 0.00^{\mathrm{a}}$ & $0.55 \pm 0.00^{\mathrm{a}}$ & $22.33 \pm 0.58^{\mathrm{a}}$ & $1.29 \pm 0.01^{\mathrm{a}}$ \\
\hline
\end{tabular}

*Aynı sütundaki farklı küçük harfle belirtilen değerlerin istatistiksel olarak önemli ölçüde farklı olduğunu belirtmektedir. $\mathrm{p}<0.05$. ortalama \pm ;standart sapma

Toz gıda ürünlerinin toz özellikleri işleme, depolama ve son ürün hazırlama süreçlerini etkilemektedir. Toz akış özelliklerinin başında yığın ve sıkıştırılmış yoğunluk ve bu değerlerden elde edilen Carr indeksi ile Hausner oranı değerleri gelmektedir.

Yığın yoğunluk değeri tuz ilaveli ve kontrol grubu pul biberleri için $0.38-0.43 \mathrm{~g} / \mathrm{cm}^{3}$ aralığında belirlenmiştir. $\% 3$ oranında tuz içeren pul biber örneği ve kontrol grubu pul biberin yığın yoğunluk değerleri istatistiksel açıdan farksız bulunmuştur $(\mathrm{p}>0.05)$. Öte yandan pul bibere $\% 5$ ve $\% 7$ oranında tuz ilavesi yığın yoğunluk değerini arttırmıştır. Benzer sonuçlar sıkıştırılmış yoğunluk değerinde de tespit edilirken $\% 5$ ve $\% 7$ oranında tuz ilavesi sıkıştırılmış yoğunluk değerinde artışa neden olmuştur. Yüksek yığın yoğunluğuna sahip toz ürünler paketleme, nakliye ve depolama prosesleri için doğru ve tercih edilen ürünlerdir. Toz ürünün yüksek yığın yoğunluğun olması için pürüzsüz, tek tip boyutta ve küresel şekilli olmas1 gerekmektedir (Bicudo ve ark., 2015). Tuz ilavesi ve oran artışı pul biberlerin istenilen toz özelliklere sahip olmasını sağlamıştır. Ayrıca düșük yığın yoğunluğu toz parçacıkları arasında fazla boşluk olması nedeniyle düşük depolama stabilitesine sahip ürünlere neden olmaktadır (Koç ve ark., 2011). Öte yandan sıkıştırılmış yoğunluk değerleri yığın yoğunluk değerlerinden ve tuz ilaveli örneklerde KontrolPB'den yüksek bulunmuştur. Bu durum partikül boyutu yüksek olan ürünlerin bileşiminde bulunan küçük partiküllü ürünlerin analiz sırasındaki vurma işlemi ile boşlukları doldurduğu ve etkin paketleme olanağı sağladığ şeklinde açıklanmaktadır (Mitra ve ark., 2017).

Carr indeks sonuçları akış özellikleri tanımlamasında kullanılmaktadır. Elde edilen veriler ışı̆̆ında 'çok iyi' toz akış ifadesi Carr indeks değer \%15'den küçük ise kullanılmaktadır. Öte yandan 'iyi' tanımlaması için Carr indeks değeri \%15-20 değerleri aralığında, 'orta' değeri için ise \%20-35 aralığında olmalıdır. Carr indeks değerine göre 'kötü' akış \%35-45 değerleri arasında, 'çok kötü' akıș ise Carr indeks değerinin >\%45 olması durumunda elde edilir (Santhalakshmy ve ark., 2015). Pul biber örneklerinin Carr indeks değerleri ürüne eklenen tuz oranı arttıkça artış gözlenmiştir. Analiz sonucuna göre \%18.67 değeri ile Kontrol-PB 'iyi', \%20.47, \%22.00 ve \%22.33 değerleri ile PB3, PB5 ve PB7 ürünleri 'orta' akış özelliği göstermişlerdir. Ayrıca tuz oranının \%5'den \%7 çıkması Carr indekste anlamlı bir değişim yapmamıştır $(\mathrm{p}>0.05)$.

Hausner oranı ise toz ürünlerde kohezyon tanımlamasında kullanılmaktadır ve toz tanelerinin yapışma eğilimi ve sıkışabilmesi hakkında bilgi vermektedir (Acartürk ve ark., 2009). Hausner oran1 1.2'den düşükse 'düşük', 1.2-1.4 aralığında 'orta', 1.4'den büyükse 'yüksek' kohezyonu ifade etmektedir (Santhalakshmy ve ark., 2015). Çalışma sonucunda pul biber örneklerinin Hausner oranları tuz oranı artış1 ile artmaktadır. Fakat tüm pul biber örneklerinin orta kohezyon özellik gösterdikleri belirlenmiştir. 


\section{Toz Akış Özellikleri}

Toz akış özelliklerinin en temelde toz karışımın bileșiminde bulunan tozların nem içeriği, partikül büyüklüğü ve yapısından etkilendiği bilinmektedir

Farklı oranlarda tuz ilave edilmiş pul biber örneklerinin toz akış özellikleri kohezyon testi, toz akış hızı bağımlılık testi (PFSD testi) ve kekleşme testi (caking test) başlıkları altında değerlendirilmiştir. Şekil 1'de örneklerin kekleşme ve kohezyon test grafikleri verilmiştir. Toz ürünlerin kekleşme yükseklik oranı her döngüdeki kekleşme yükseklik oranının başlangıçtaki sütun yüksekliğine bölünmesi ile hesaplanırken, kohezyon indeksi analiz başlamadan belirlenen örnek ağırlığına kohezyon katsayısının bölünmesi ile hesaplanmaktadır (Bansal ve ark., 2017).
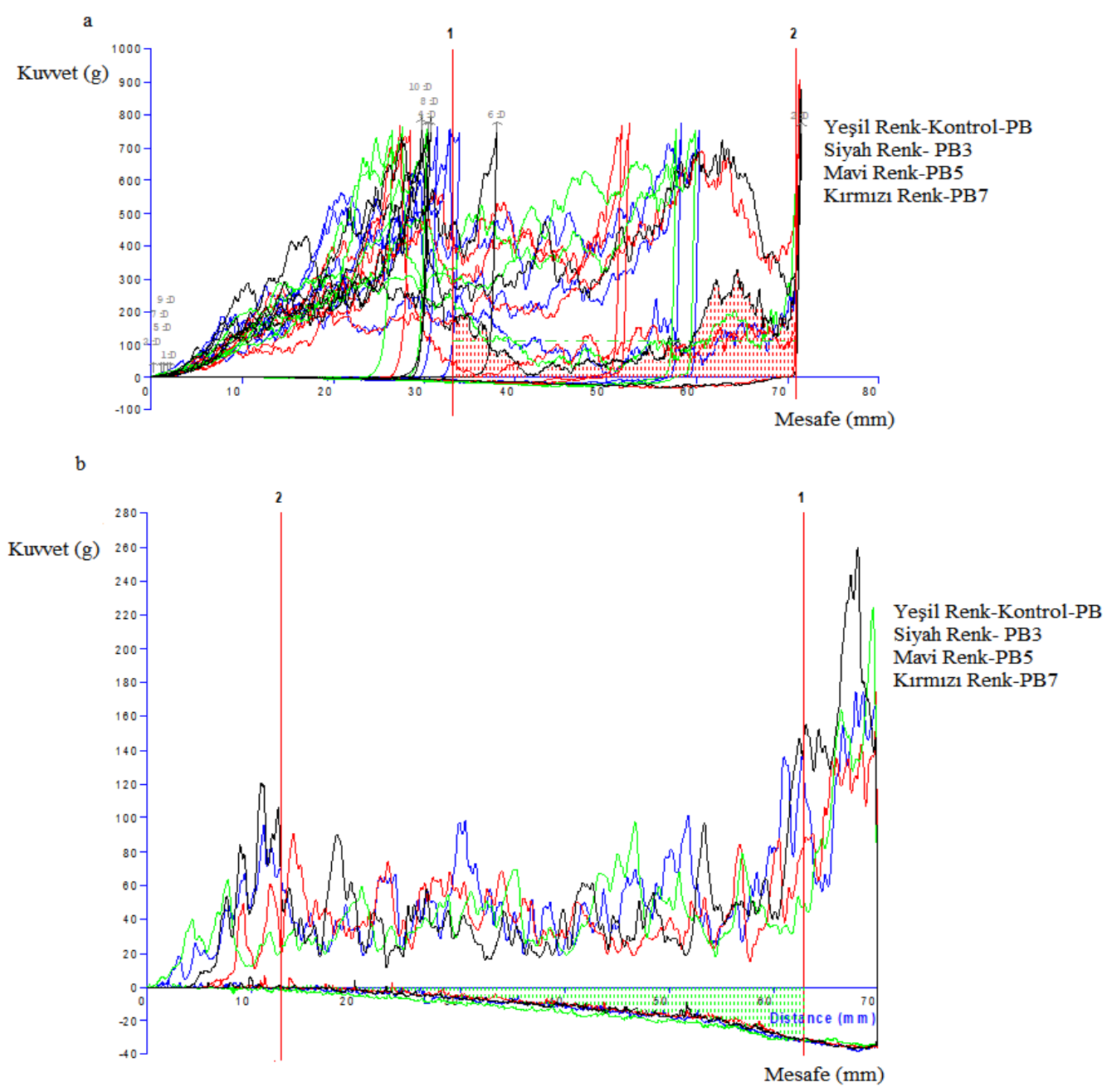

Şekil 1. Pul biber örneklerinin a) kekleşme testi b) kohezyon testi grafikleri 
Tuz Oranı Değişiminin Kırmızı Pul Biberin Toz Akış Özellikleri Üzerine Etkisi

Çizelge 3. Ürünlerin kohezyon indeksi değerleri ve akış özellikleri

\begin{tabular}{ccc}
\hline Örnekler & Kohezyon İndeksi & Ak1ş Özelliği \\
\hline Kontrol-PB & $12.17 \pm 0.18^{\mathrm{a}}$ & Kolay ak1ş \\
PB3 & $10.85 \pm 0.22^{\mathrm{b}}$ & Serbest ak1ş \\
PB5 & $9.54 \pm 0.07^{\mathrm{c}}$ & Serbest ak1ş \\
PB7 & $9.17 \pm 0.04^{\mathrm{c}}$ & Serbest ak1ş \\
\hline Ayn1 sütundaki farklı harfler örnekler arası farkın istatistiksel olarak önemli olduğunu gösterir. Ortalama \pm standart sapma
\end{tabular}

Pul biber örneklerinin kohezyon indeksi ve toz akış özellikleri Çizelge 3'de verilmiştir. Örneklerin akış özellikleri daha önceden kohezyon indeksi değerleri temel alınarak yapılan ölçek incelenerek hazırlanmıştır (Benkovic ve Bauman, 2009). Tuz oranı artış1 pul biberlerin kohezyon indeksi değerlerini azaltırken akış özelliklerini 'kolay akış' tanımlamasından 'serbest akışa' dönüştürmüştür. Toz akış analizi ile elde edilen akış özellikleri Carr indeks sonuçları ile paralellik göstermektedir. Kuru tozlar genelde serbest akış davranışı göstermektedirler, daha nemli ürünler ise taşıma depolama zorluklarına neden olurlar. Ayrıca kuru ürünler yüksek nemli ortamlarda bulunduklarında yapılarına su çekip akış özelliklerini değiştirmeye meyillidirler (Juarez-Enriquez ve ark., 2017). Öte yandan toz ürünlerin tanecik boyutu azaldığında kohezyon indeksi değerlerinin de azaldığ (Göksel Saraç ve ark., 2020). Tuz ilavesi ile pul biberlerin azalan tanecik boyutu kohezyon indeksi sonuçlarının azalmasına neden olmuştur.
Toz ürünlerin sıkıştırılmaya maruz kalmaları akış özelliklerini etkilemektedir. Pul biber örneklerinde değişen sıkıştırma döngüsü değerleri sıkışma katsayılarını da değiştirmiştir (Şekil 2). En düşük sıkıştırma katsayısı sonuçları $50 \mathrm{~mm} / \mathrm{s}$ sıkıştırma döngüsünde elde edilmiştir. Tuz ilavesi ve oran artışı sıkıştırma katsayılarını azaltmıştır. Toz ürünlerin akış hızları uygulanan akış davranış şekli ile değişiklik gösterebilir. Tozlar daha hızlı akmaya zorlandığında direnç gösterebilir ya da daha serbest bir akış kazanması sağlanabilir (Doğan ve ark., 2019). Tuz ilavesi pul biberlerin daha kolay akmasinı sağlamıştır. Bu durum toz ürünlerin kohezyon özelliklerinin başta partikül boyutu, şekli ve gözenek yapısı olmak üzere nem miktarı ve elektrostatik aktivite gibi değişkenlerden etkilenmesi durumuyla açıklanabilir (Thomas ve ark., 2004).

Çizelge 4. Pul biberlerin akış stabilitesi ve $50 \mathrm{~mm} / \mathrm{s}$ 'deki kohezyon katsayısı değerleri

\begin{tabular}{ccc}
\hline Örnekler & Akış Stabilitesi Değerleri & Kohezyon Katsayıs1 $(\mathrm{g} . \mathrm{mm})$ \\
\hline Kontrol-PB & $0.91 \pm 0.05^{\mathrm{a}}$ & $-860.24 \pm 4.71^{\mathrm{c}}$ \\
PB3 & $0.89 \pm 0.02^{\mathrm{ab}}$ & $-771.22 \pm 11.51^{\mathrm{a}}$ \\
PB5 & $0.86 \pm 0.03^{\mathrm{ab}}$ & $-764.21 \pm 6.51^{\mathrm{a}}$ \\
PB7 & $0.82 \pm 0.07^{\mathrm{b}}$ & $-798.14 \pm 12.39^{\mathrm{b}}$
\end{tabular}

Aynı sütundaki farklı harfler örnekler arası farkın istatistiksel olarak önemli olduğunu gösterir. Ortalama \pm standart sapma 


\section{Tuz Oranı Değiş̧iminin Kırmızı Pul Biberin Toz Akış Özellikleri Üzerine Etkisi}

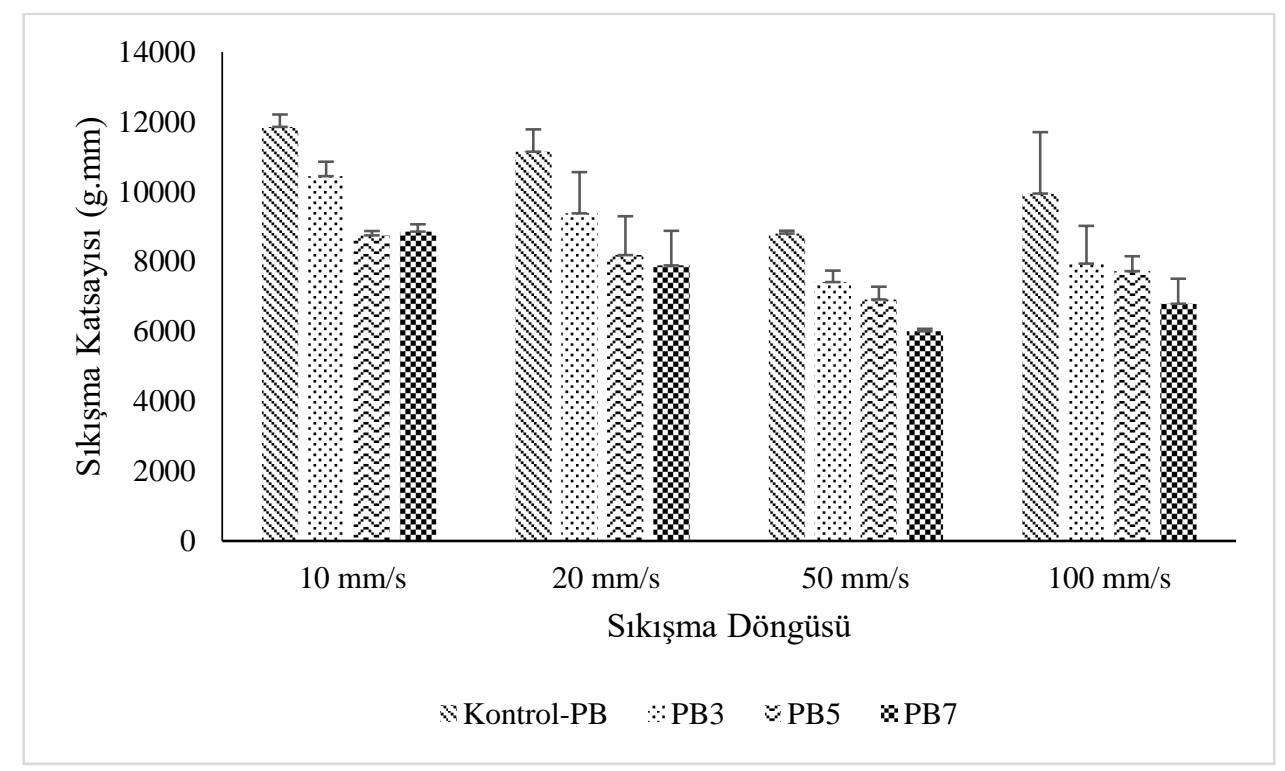

Şekil 2. PFSD testinde artan test hızlarına bağlı olarak örneklerin sıkışma katsayısı değerleri

Toz akış değerlendirmelerinden olan akış stabilite ve kohezyon katsayısı değerleri incelendiğinde tuz oranı artışının akış stabilite değerini azalttığı ve örneklerin akış stabilite değerlerinin $\quad 0.82-0.91$ aralığında olduğu saptanmıştır (Çizelge 4). Tuz ilavesi ile kohezyon katsayısında artış tespit edilmiştir. Öte yandan PB3 ve PB5 örneklerinin kohezyon katsayıları arasında bir fark bulunamamıştır $(\mathrm{p}>0.05)$. Örneklerin kohezyon katsay1lar1 764.21- (-860.24) g.mm aralığında belirlenmiştir. Akış stabilite değeri 1'den farklı ise örnek analiz esnasında değişime uğramış demektir. Bu değişim örnekte meydana gelen hasar1 ve aglomerasyonu ifade etmektedir (Doğan ve ark., 2019).

Şekil 3'de örneklerin değişen döngü sayısına karşı1ık kekleşme yükseklik oranları verilmiştir. Artan döngü sayısı tüm örneklerde kekleşme yükseklik oranlarını artırmıştır. Tuz ilaveli pul biberlerin kekleşme yükseklik oranları kontrol grubuna göre yüksek bulunmuştur. Tuz ilave edilmemiş pul biberlerin 2., 3 . ve 4 . döngülerinde kekleşme yükseklik oranları sabit kalırken 5.döngüde yine artış gözlenmiştir. PB3, PB5 ve PB7 örneklerinin kekleşme yükseklikleri yakın değerlerde bulunurken 4 . ve 5. döngüde yükseklik oranı değişimleri gözlenmemiştir. Değișen döngü sayısı ile kekleşme yüksekliğinde karşılaşılan ani artışlar toz ürünlerin topaklaşmaya olan eğilimlerini göstermektedir (Mercan ve ark., 2018). Tuz kekleşme sorunu yaşayan toz bir ürün olması nedeniyle kekleşme önleyici gıda katkı maddelerinin kullanıldığ 1 ve üzerinde kekleşme önleyici karışımlar için araştırmalar yapılan bir üründür (Geertman, 2005; Lück ve von Rymon Lipinski, 2000). Öte yandan toz kırmızıbiber ve tuz 'yapışkan olmayan' toz ürünler olarak tanımlanmaktadır. Tuz nemi yüzeyinde absorbe ederken toz biber gözenekli yapısı nedeniyle daha çok su absorbe eden bir üründür. Fakat yapılan bir çalışmada toz biber ve tuz karışımlarında incelenmesi sonucunda tuzun daha yüksek kekleşme sağladığı belirlenmiştir (Fitzpatrick ve Bremenkamp, 2019). 


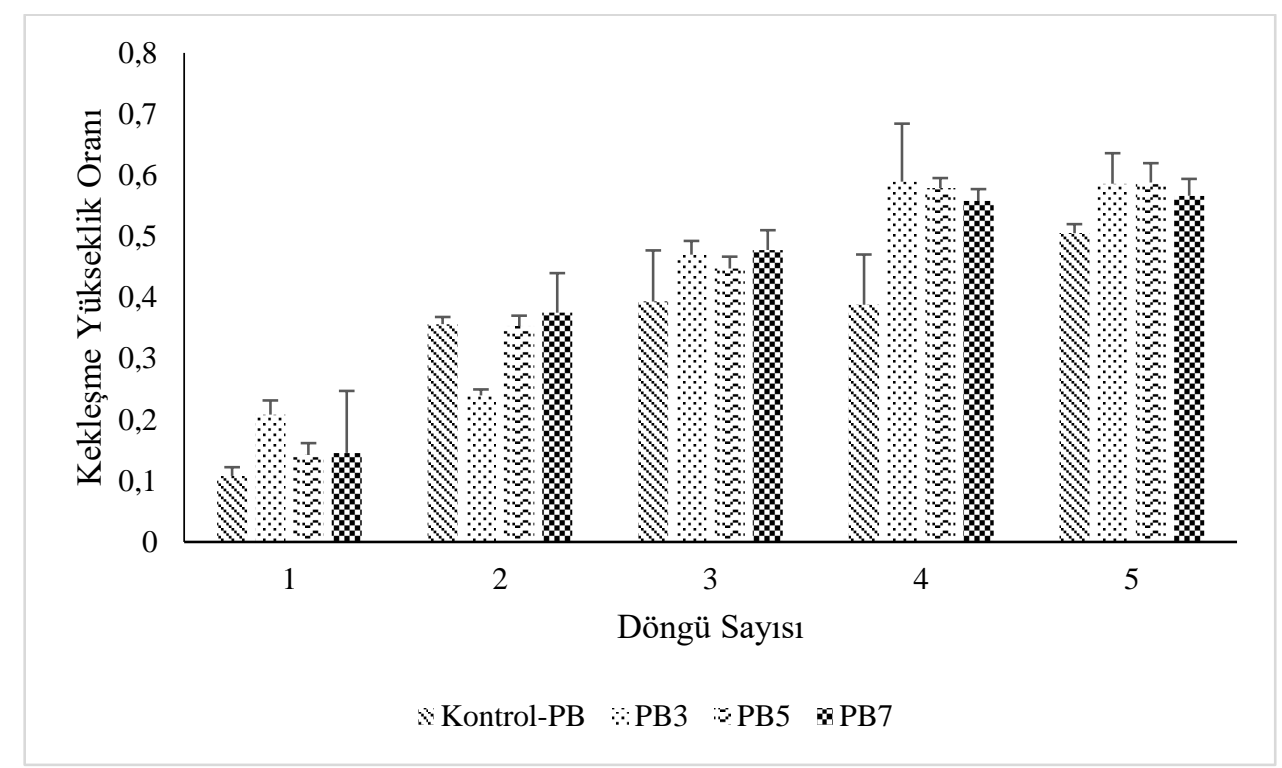

Şekil 3. Örneklerin her bir döngüde gösterdikleri kekleşme yükseklik oranı değerleri

Çizelge 5. Örneklerin ortalama kekleşme kuvveti değerleri

Örnekler Ortalama Kekleşme Kuvveti

\begin{tabular}{cl}
\hline $\begin{array}{c}\text { Kontrol- } \\
\text { PB }\end{array}$ & $127.28 \pm 1.10^{\mathrm{a}}$ \\
PB3 & $119.35 \pm 0.41^{\mathrm{b}}$ \\
PB5 & $111.94 \pm 2.72^{\mathrm{c}}$ \\
PB7 & $103.11 \pm 2.79^{\mathrm{d}}$ \\
\hline
\end{tabular}

Çalışma kapsamında kullanılan pul biber örneklerinin ortalama kekleşme kuvveti sonuçları Çizelge 5'de görülmektedir. PFSD testleri incelendiğinde tuz ilavesi gerçekleşmiş pul biberlerin akışının daha kolay olduğu gözlenmiştir. Öte yandan tuzun ve pul biberin yapıları gereği kekleşmeye meyilli olmaları karıșım halinde kullanıldıklarında kekleşme derecelerinin artmasina neden oldukları belirlenmiştir. Bu aşamada tuz ilavesi ile iyileşen toz akış karakteristiğinin kekleşmede yaşanan sorunun çözümü ile istenilen noktaya getirileceği düşünülmektedir. Kekleşme önleyici gıda katkı maddesi olarak kullanılan ürünlerden pul biberde karşılaşılan kekleşme sorununun çözülmesi için ürün karışımlarına eklenebileceği düşünülmektedir.

En yüksek ortalama kek kuvveti Kontrol-PB örneğinde en düşük değer ise PB7 örneğinde belirlenmiştir. Tuz oran artışı ile ortalama kekleşme kuvveti azalmıştır.

\section{Sonuc}

Toz ürünlerin özelliklerinin ve toz akış karakteristiklerinin belirlenmesi mühendislik uygulamalarında ürün işleme, ambalajlama ve depolama süreçlerinde önemlidir. Ürün tartım, ambalaj malzemesi ve boyutu seçimi, karıştırma işlemleri ve karışım ürünlerde ürün formülasyonu oluşturma, üretim hatlarında ürün 


\section{Tuz Oranı Değişiminin Kırmızı Pul Biberin Toz Akış Özellikleri Üzerine Etkisi}

transferi ve depolama süreçlerinde toz akış özelliklerine göre planlama yapılması gerekmektedir. Son zamanlarda bu konular üzerinde yapılan araştırmalar artmaktadır. Toz ürün grupları içerisinde önemli yer tutan baharatlardır ve baharatlar içerisinde en çok tüketilen ürün toz kırmızıbiberlerdir. Çalışmada pul biberlere ilave edilen ve yasal sinırlar ile miktarları belirlenmiş tuzun üründe toz akış üzerinde yaptığı etkiler belirlenmiştir. Tuz ilavesi ve oran artışı ile yığın yoğunluk analizi sonucunda depolama süreçlerinde istenilen karakterde ürün oluşumuna neden olan yüksek yığın yoğunluk değerleri elde edilmiştir. Benzer şekilde ambalajlama özelliklerinin belirlenmesi için sıkıştırılmış yoğunluk değeri temel alındığında, tuz ilavesinin aynı ağırlıkta kontrol pul biberi içeren ambalaja göre daha etkin ambalaj kullanım imkânı sağladığı tespit edilmiştir. Ayrıca toz akış özelliklerinden kohezyon ve PFSD testleri incelendiğinde tuz ilavesi gerçekleşmiş pul biberlerin akışının daha kolay olduğu gözlenmiştir. Öte yandan tuzun ve pulbiberin yapıları gereği kekleşmeye meyilli olmaları, karışım halinde kullanıldıklarında kekleşme derecelerinin artmasına neden olmaktadır. Bu aşamada tuz ilavesi ile iyileşen toz akış karakteristiğinin kekleşmede yaşanan sorunun çözümü ile istenilen noktaya getirileceği öngörülmektedir. Kekleşme önleyici gıda katkı maddesi olarak kullanılan ürünlerden pul biberde karşılaşılan kekleşme sorununun çözülmesi için ürün karışımlarına eklenebileceği düşünülmektedir.

\section{Kaynaklar}

Acartürk, F., Çelebi, N., Değim, T., Değim, Z., Doğanay, T., Takka, S., Tirnaksız, F., Ağabeyoğlu, İ. (2009) Modern Farmasötik Teknoloji, Türk Eczacılar Birliği Eczacılık Akademisi Yayını.

Akgün, B., Genç, S., Arıcı, M. (2018) Tuz: Gıdalardaki Algısı, Fonksiyonları ve Kullanımının Azaltılmasına Yönelik Stratejiler. Akad Glda 16, 361-370.

Alonso-Miravalles, L., Zannini, E., Bez, J., Arendt, E.K., O'Mahony, J.A. (2020) Physical and flow properties of pseudocereal-based protein-rich ingredient powders. J Food Eng. 281, 109973.

Arimboor, R., Natarajan, R.B., Menon, K.R., Chandrasekhar, L.P., Moorkoth, V. (2015) Red pepper (Capsicum annuum) carotenoids as a source of natural food colors: analysis and stability-a review. $J$ Food Sci Technol 52(3), 1258-1271.

Bansal, V., Premi, M., Sharma, H.K., Nanda, V. (2017) Compositional, physical, functional attributes and flow characterization of spray-dried skim milk powder enriched with honey. J Food Meas Charact 11, 1474-1485.

Benkovic, M., Bauman, I. (2009) Flow properties of commercial infant formula powders. World Acad Sci Eng Technol 54, 495-499.

Bicudo, M.O.P., Jó, J., Oliveira, G.A. de, Chaimsohn, F.P., Sierakowski, M.R., Freitas, R.A. de, Ribani, R.H. (2015) Microencapsulation of Juçara (Euterpe edulis M.) Pulp by Spray Drying Using Different Carriers and Drying Temperatures. Dry Technol 33, 153-161.

Chitrakar, B., Zhang, M., Adhikari, B. (2018) Dehydrated foods: Are they microbiologically safe? Crit Rev Food Sci Nutr 59, 2734-2745.

Choi, E.J., Yang, H.S., Park, H.W., Chun, H.H. (2018) Inactivation of Escherichia coli O157:H7 and Staphylococcus aureus in red pepper powder using a combination of radio frequency thermal and indirect dielectric barrier discharge plasma nonthermal treatments. LWT 93, 477-484.

Dağhan, Ş. (2015) Farklı kurutma metodlarının pul biber kalitesi ve kurutma kinetiği üzerine etkisi. Harran Üniversitesi.

Dhanalakshmi, K., Ghosal, S., Bhattacharya, S. (2011) Agglomeration of food powder and applications. Crit Rev Food Sci Nutr 51, 432-441.

Doğan, M., Aslan, D., Gürmeriç, V., Özgür, A., Göksel Saraç, M. (2019) Powder caking 
and cohesion behaviours of coffee powders as affected by roasting and particle sizes: Principal component analyses (PCA) for flow and bioactive properties. Powder Technol 344, 222-232.

Fitzpatrick, J.J., Bremenkamp, I. (2019) Investigation of the effect of time on the humidity caking of food powder binary mixes using a cake strength tester and visual techniques. J Food Eng 263, 195203.

Geertman, R.M. (2005) How to make salt rust or: New anticaking agents for salt, in: VDI Berichte. pp. 557-562.

Giuffrida, D., Dugo, P., Torre, G., Bignardi, C., Cavazza, A., Corradini, C., Dugo, G. (2014) Evaluation of carotenoid and capsaicinoid contents in powder of red chili peppers during one year of storage. Food Res Int 65, 163-170.

Gobie, W. (2019) A seminar review on red pepper (Capsicum) production and marketing in Ethiopia. Cogent Food Agric $5,1-14$.

Göksel Saraç, M., Aslan Türker, D., Dogan, M., 2020. Ticari öneme sahip toz süt ürünlerinin morfolojik yapısı ve toz akış özelliklerinin belirlenmesi. Glda / J Food 46, 119-133.

Guclu, G., Keser, D., Kelebek, H., Keskin, M., Emre Sekerli, Y., Soysal, Y., Selli, S.(2021) Impact of production and drying methods on the volatile and phenolic characteristics of fresh and powdered sweet red peppers. Food Chem 338, 129128.

Jan, S., Rafiq, S.I., Saxena, D.C. (2015) Effect of physical properties on flow ability of commercial rice flour/powder for effective bulk handling. Int J Comput. Appl 0975, 15 .

Jaya, S., Das, H. (2004) Effect of maltodextrin, glycerol monostearate and tricalcium phosphate on vacuum dried mango powder properties. J Food Eng 63, 125-134.
Jiao, S., Zhang, H., Hu, S., Zhao, Y. (2019) Radio frequency inactivation kinetics of Bacillus cereus spores in red pepper powder with different initial water activity. Food Control 105, 174-179.

Juarez-Enriquez, E., Olivas, G.I., ZamudioFlores, P.B., Ortega-Rivas, E., Perez-Vega, S., Sepulveda, D.R. (2017) Effect of water content on the flowability of hygroscopic powders. J Food Eng 205, 12-17.

Kirk, R.S., Sawyer, R. (1991) Pearsons Compostion and Analysis of Foods. Longmans Scientific and Technical.

Koç, M., Koç, B., Yilmazer, M.S., Ertekin, F.K., Susyal, G., Bağdatlioğlu, N. (2011) Physicochemical characterization of whole egg powder microencapsulated by spray drying. Dry Technol 29, 780-788.

Korkmaz, A., Atasoy, A.F., Hayaloglu, A.A. (2020) Changes in volatile compounds, sugars and organic acids of different spices of peppers (Capsicum annuum L.) during storage. Food Chem 311, 125910.

Lee, H.S., Park, H.H., Min, S.C. (2020) Microbial decontamination of red pepper powder using pulsed light plasma. J Food Eng 284, 110075.

Lück, E., von Rymon Lipinski, G.-W. (2000) Foods, 3. Food Additives, in: Ullmann's Encyclopedia of Industrial Chemistry.

Mercan, E., Sert, D., Akın, N. (2018) Determination of powder flow properties of skim milk powder produced from highpressure homogenization treated milk concentrates during storage. LWT 97, 279288.

Mitra, H., Pushpadass, H.A., Franklin, M.E.E., Ambrose, R.P.K., Ghoroi, C., Battula, S.N. (2017) Influence of moisture content on the flow properties of basundi mix. Powder Technol 312, 133-143.

Rico, C.W., Kim, G.R., Ahn, J.J., Kim, H.K., Furuta, M., Kwon, J.H. (2010) The comparative effect of steaming and irradiation on the physicochemical and 
microbiological properties of dried red pepper (Capsicum annum L.). Food Chem 119, 1012-1016.

Santhalakshmy, S., Don Bosco, S.J., Francis, S., Sabeena, M. (2015) Effect of inlet temperature on physicochemical properties of spray-dried jamun fruit juice powder. Powder Technol 274, 37-43.

Schweiggert, U., Carle, R., Schieber, A. (2007) Conventional and alternative processes for spice production - a review. Trends Food Sci Technol 18, 260-268.

Song, Y., Du, B., Ding, Z., Yu, Y., Wang, Y. (2021) Baked red pepper (Capsicum annuum L.) powder flavor analysis and evaluation under different exogenous Maillard reaction treatment. LWT 139, 110525 .

Staack, N., Ahrné, L., Borch, E., Knorr, D. (2008) Effect of infrared heating on quality and microbial decontamination in paprika powder. J Food Eng 86, 17-24.

Tatar, F. (2012) Balık (Engraulis encrasicolus L.) Yağının Mikroenkapsülasyonunda Hemiselülozun Kaplayıcı Madde Olarak Kullanımı. Ondokuz Mayıs Üniversitesi.

Teunou, E., Fitzpatrick, J.J., Synnott, E.C.
(1999) Characterization of food powder flowability. J Food Eng 39, 31-37.

Thomas, M.E.C., Scher, J., Desobry-Banon, S., Desobry, S. (2004) Milk powders ageing: Effect on physical and functional properties. Crit Rev Food Sci Nutr 44, 297322.

Yapıc1, E., Karakuzu-İkizler, B., Yücel, S. (2021) Anticaking additives for food powders, in: Food Engineering Series. pp. 109-123.

Zhang, B., Zhang, L., Cheng, T., Guan, X., Wang, S. (2020) Effects of water activity, temperature and particle size on thermal inactivation of Escherichia coli ATCC 25922 in red pepper powder. Food Control $107,106817$.

Zhang, H., Zhao, Y., Gong, C., Jiao, S. (2020) Effect of radio frequency heating stress on sublethal injury of Salmonella Typhimurium in red pepper powder. $L W T$ $117,108700$.

Zou, Y., Brusewitz, G.H. (2002) Flowability of uncompacted marigold powder as affected by moisture content. J Food Eng 55, 165171. 